$\sqrt{B}$

J. Bio-Sci. 29(1): 23-31, 2021 (June)

ISSN 1023-8654

http://www.banglajol.info/index.php/JBS/index

DOI: https://doi.org/10.3329/jbs.v29i0.54819

\title{
MORPHOMETRIC CHARACTERS AND SEX RATIO OF THE FRESHWATER GARFISH, XENENTODON CANCILA COLLECTED FROM DIFFERENT WATERS OF JASHORE, SOUTH-WESTERN BANGLADESH
}

\author{
MS Islam* and P Laboni \\ Department of Fisheries and Marine Bioscience, Jashore University of Science and Technology, Bangladesh
}

\begin{abstract}
The freshwater garfish, Xenentodon cancila is one of the important food fish in Bangladesh. The size class distribution, length-weight relationships, and sex ratio of $X$. cancila are described in the present study. A total of 138 specimens were collected randomly for a year from the local fish markets and/or direct from fishermen who fish primarily in nearby waters (Beel, Canal and Baor) of Jashore, southwestern Bangladesh. Most individuals were collected in the rainy season and their mean size was larger compare to the other two seasons (summer and winter). The maximum size recorded $254.1 \mathrm{~mm}$ total length (TL) and $38.05 \mathrm{~g}$ body weight (BW). The mean $\mathrm{TL}$ and BW were $166.35 \pm 38.17 \mathrm{~mm}$ and $11.16 \pm 7.47 \mathrm{~g}$, respectively. Most of the individuals belonged to the size class of $141-180 \mathrm{~mm}$. The length-weight relationship (LWR) was strongly correlated as the regression value was 0.876 and the relationships were linear in both sexes. The allometric coefficient ' $b$ ' of the LWR indicated nearly positive allometric growth and the value was 2.98. The male fishes were dominant over females and the ratio was 1: 0.77 . These research outcomes would be useful for the researcher to better understand the biological aspects of freshwater garfish in the nearby waters of Jashore area in south-western Bangladesh.
\end{abstract}

Key words: Morphometric characters, Length-weight relationship, Sex ratio, Size-class distribution, Xenentodon cancila

\section{Introduction}

Xenentodon cancila (Hamilton 1822) is one of the important small indigenous fish in Bangladesh. It is known as 'freshwater garfish' commonly found in freshwater and brackish water. The fish is locally known as Kaikka (Rahman 1989), Kakila 'Gar' (Al-Mamun 2003) and Kankely (Nath and Dey 1989) in Bangladesh. X. cancila principally dominant in rivers (Talwar and Jhingran 1991) but also found in ponds, canals, beels (large bowl-shaped depressions), and inundated fields throughout the year in the country (Rahman 2005, Hussain et al. 2012). The fish reported in the most of the area of greater Jashore region but in less abundant (Islam 2015) and reported from the upstream river of Kopothakho, canals (Shagda, Bakura, Shimulia, Sharsha); beels (Vabadah, Khatura, Noyali, Dumurkhali, etc.) and baors (Ber Gobindopur and Jhapa).

The fish not only palatable table fish but also potential aquarium species. It is rich in protein (14.27\%) and lipid (4.66\%) which can help people suffering from malnutrition and protein deficiency (Nahid et al. 2016). It also contains calcium $(0.94 \%)$ and phosphorus (2.14\%) which are important for metabolism, bone formation etc (Hossain 1999). Though the fish is demandable in the market, not yet introduce as culture fish and fully

*Author for correspondence: dms.islam@just.edu.bd 
harvested from the natural water body. The major part of the catch of the country is consumed locally and a small part is exported to the Middle East, Europe, and America (Talwar 1999, Frose 2012).

Morphometric characters of fish are the measurable characters common to all fishes. The morphometric analysis of fish is a fundamental key in the biological study of fish (Hussain et al. 2012). The growth of the body parts is proportional to the growth of the total length. So, morphometric measurement of fishes and the study of the statistical relationship among them are essential for the taxonomic study of a species (Tandon et al. 1993). The size-class distribution gives us an idea about the status of the fishes in a given water body/area. The length-weight relationship (LWR) is a mathematical analysis between length and weight to reveal how they are related to each other in the study of fish biology (Chandrika and Balasubramonian 1986, Hossain et al. 2016 \& 2017). Knowledge of 'LWR' is very important for fish culture, fisheries management, and comparative growth studies (Rahman et al. 2019). In addition, knowledge of sex ratio of catches is to help in understanding whether any sexual differential fishing exist and to know the appropriate number of male and female for natural propagation in a given habitat (Hossain et al. 2012). Catch demography, sex ratio, and size classes are the basic information to understand the status of fish which is useful in fishery management (Vazzoler 1996, Khatun et al. 2019, Hasan et al. 2021).

There are several studies have been done on the morphometric relationship of the native fishes in Bangladesh notably Hossain (2010), Hossain et al. (2013, 2016 \& 2017), Alam et al. (2013), Hossain et al. (2015), and Islam et al. (2017). However, the studies on X. cancila in the country are very few. Hussain et al. (2012) conducted research on the morphometric characters of the fish from Rajshahi; Hossain et al. (2013) studied the life-history traits from the Ganges River, northwestern Bangladesh, and Mian et al. (2017) reported on the reproductive aspects of the fish from north-east Bangladesh. There is no study on the morphometric characteristics and LWR on the species from any minor habitats (for $X$. cancila) such as canals, beels, and baors in the country. For the understanding of the health and biological status of $X$. cancila in these waters, detailed knowledge on the fish demography, length-weight relationship, and sex ratio are the important parameters. Therefore, the present study aims to find the samples' demography, sex ratio, size-class distribution, and length-weight relationship of $X$. cancila caught from the different minor water systems such as canals, beels, and baors in Jashore area, south-western Bangladesh.

\section{Materials and Methods}

\section{Sample collection and preservation}

The fishes were collected from the local fish markets and/or directly from fish collectors whenever possible for a year. However, it was always taken best care to make sure that the fishes were harvested from the nearby water habitats. The survey was conducted in the local markets namely Borobazar, Palbari, Saluya, Ambottola, Monirampur in each month where fishes gather mostly from the waters of the baor (Jhapa baor), beels (Vabadah, Noyali), and canals (Shagda and Bakura). It is noted that the fish is not available in the locality year-round and was not possible to separate the samples from a single habitat. Thus, in the present study, the collected fishes are considered as the common fish of the minor water habitats as the fish is predominant in the river system (Talwar and Jhingran 1991). The sampled fishes were preserved in 10\% formalin solution and brought to the laboratory of the Fisheries and Marine Bioscience department of Jashore University of Science and Technology for further investigation. 


\section{Morphometric measurement}

In the laboratory, each fish was measured for the total length (TL), and body weight (BW) to the nearest $\mathrm{mm}$ and gram by using a slide caliper (Electronic digital caliper) and electronics balance (A\&D company, Model: EK 1200i; Japan) respectively. The individuals were classified into different size classes according to their length intervals.

\section{Demographic analysis}

To know the demographic status of the fish, samples were analyzed with Microsoft Excel to calculate the mean size and weight, maximum-minimum size, and weight of the male, female, and combined sexes. The data also analyzed on a seasonal basis (winter, summer and rainy) to better understand the life traits of the fish.

\section{Determination of the length-weight relationship}

The length-weight relationships of the collected specimens were estimated by the allometric formula, $W=a$ $+b L$. Where, "W" is dependent variables (i.e., total body weight in g) and "L" is independent variables (i.e., total length in $\mathrm{mm}$ ), "a" is the intercept of the regression, and "b" is the regression coefficient (slope). Parameters "a" and "b" of the length-weight relationship were estimated by linear regression analysis based on natural logarithms:

$$
\operatorname{Ln}(W)=\operatorname{Ln}(a)+\operatorname{LIn}(b)
$$

Statistical significance of $b$ value determined by isometric range $(b=3)$ or allometric range (negative allometric; $b<3$ or positive allometric; $b>3$ ) (Sokal and Rohlf 1987, Hossain et al. 2013).

\section{Sex ratio}

The gonad of the specimens was dissected and observed to identify the sexes. Then sex ratio was calculated monthly and the number of both sexes was plotted against months and seasons in percentage. A Chi-square test was done to find out the sex ratio for the difference, if any, from hypothetical ratio 1:1.

\section{Results and Discussion}

\section{Morphometric characters}

The morphometric demography of the fishes in respected to total length (TL), and body weight (BW) is presented in Table 1. The largest individual recorded $254.1 \mathrm{~mm}$ in TL and that was a female while the smallest one was male $(96 \mathrm{~mm})$. Male fishes were smaller $(230.4 \mathrm{~mm} \mathrm{TL}$ and $27.78 \mathrm{~g} \mathrm{BW}$ ) than female fishes (254.1 $\mathrm{mm}$ TL and $38.05 \mathrm{~g} \mathrm{BW).} \mathrm{Female} X$. cancila was larger than the male which is also noticed by Hossain et al. (2013) from north-western Bangladesh. The maximum length recorded in the present study was higher than other reports available on the species. In the present study, the total length was recorded $230.4 \mathrm{~mm}$ for males and 254.1 for females whereas Hossain et al. (2013) reported $189 \mathrm{~mm}$ for males and $210 \mathrm{~mm}$ for females in the Ganges River, Northwestern Bangladesh. This variation may be due to different habitats and geographical areas as fish may vary in size from area to area (Hussain et al. 2012). The sampling individuals' number and the distribution of sexes of the $X$. cancila in different seasons are given in Table 2. The maximum individuals recorded during the rainy season followed to summer and winter. The larger-size fishes are also noticed during the rainy season while the smaller size is noticed during winter. 
Table 1. The demographical presentation of $X$. cancila collected from different water systems (Beels, Canals, and Baor) in the Jashore area

\begin{tabular}{cccccccc}
\hline \multirow{2}{*}{ Number } & \multicolumn{3}{c}{ Total length $(\mathrm{mm})$} & \multicolumn{4}{c}{ Body weight $(\mathrm{g})$} \\
\cline { 2 - 7 } & & Max. & Min. & Mean \pm SD & Max. & Min. & Mean \pm SD \\
\hline Total & 138 & 254.1 & 96 & $166.35 \pm 38.17$ & 38.05 & 1.16 & $11.16 \pm 7.47$ \\
Male & 78 & 230.4 & 96 & $154.79 \pm 34.61$ & 27.78 & 1.16 & $8.75 \pm 6.01$ \\
Female & 60 & 254.1 & 100 & $181.57 \pm 37.35$ & 38.05 & 1.95 & $14.26 \pm 8.17$ \\
\hline
\end{tabular}

Table 2. The morphometric demography of $X$.cancila in different seasons for both sexes collected from nearby waters (Beels, Canals and Baor) in the Jashore area

\begin{tabular}{ccccccccc}
\hline \multirow{2}{*}{ Season } & Species & \multirow{2}{*}{ Number } & \multicolumn{4}{c}{ Length $(\mathrm{mm})$} & \multicolumn{3}{c}{ Body weight $(\mathrm{g})$} \\
\cline { 4 - 9 } & & & Max. & Min. & Mean \pm SD & Max. & Min. & Mean \pm SD \\
\hline \multirow{2}{*}{ Summer } & Total & 41 & 251.4 & 100 & $169.46 \pm 49.60$ & 31.99 & 1.66 & $12.06 \pm 9.12$ \\
& Male & 22 & 230.4 & 100 & $153.58 \pm 48.04$ & 27.78 & 1.16 & $9.31 \pm 7.86$ \\
& Female & 19 & 251.4 & 100 & $187.81 \pm 44.92$ & 31.99 & 2.60 & $15.94 \pm 9.24$ \\
\multirow{5}{*}{ Rainy } & Total & 66 & 254.2 & 103 & $173.80 \pm 31.67$ & 38.05 & 1.92 & $12.15 \pm 7.32$ \\
& Male & 35 & 229.0 & 104 & $162.15 \pm 25.97$ & 27.58 & 2.01 & $9.44 \pm 5.68$ \\
\multirow{5}{*}{ Winter } & Female & 31 & 254.1 & 103 & $186.42 \pm 32.64$ & 38.05 & 1.92 & $15.36 \pm 7.77$ \\
& Total & 31 & 219.0 & 105 & $147.61 \pm 25.90$ & 21.15 & 1.20 & $7.76 \pm 3.87$ \\
& Male & 21 & 219.0 & 105 & $145.87 \pm 28.88$ & 21.15 & 1.20 & $7.78 \pm 4.17$ \\
& Female & 10 & 185.81 & 130 & $152.64 \pm 18.53$ & 14.24 & 4.38 & $7.98 \pm 3.31$ \\
\hline
\end{tabular}

Sampled individuals were classified into different size classes according to $20 \mathrm{~mm}$ size intervals. The highest (21.01\%) numbers of individuals were under the size class of $141-160 \mathrm{~mm}$ and $161-180 \mathrm{~mm}$ respectively (Fig. 1). In the case of separate sexes, the maximum numbers (23.08\%) of males were under the size class 141-160 mm and females (26.67\%) were under the size class of 161-180 mm TL (Fig. 1). The present study revealed that there was a significant difference in size group between sexes. Most of the individuals of the waters in the Jashore area were belonging to $141-160 \mathrm{~mm}$ and 161-180 mm size class which is more or less close to the findings of Hossain et al. (2013) through different habitats. They noticed most individuals within 150-170 mm size class from Ganges River, north-western Bangladesh. In addition, the size-class distribution may vary from area to area (Hossain et al. 2012) due to different growth rates, seasons, fishing techniques etc (Wu et al. 2001, Koutrakis 2004). 


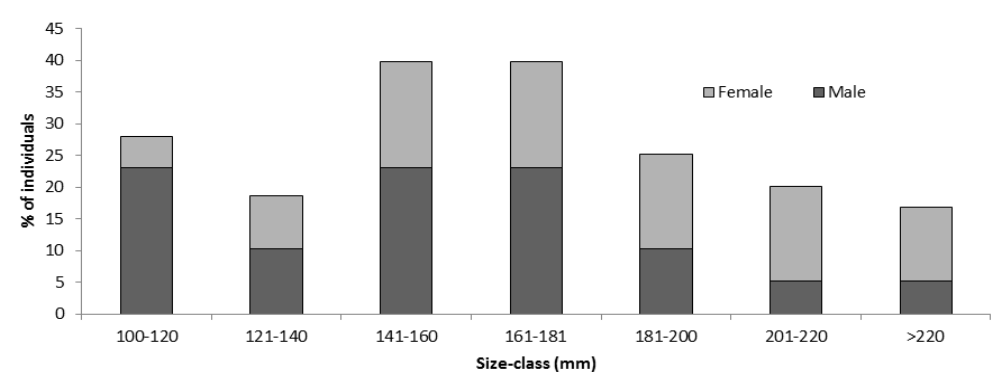

Fig. 1: Size class distribution of male-female $X$. cancila collected from nearby waters (Beels, Canals and Baor), Jashore, south-western Bangladesh.

\section{Sex ratio}

Among the collected specimens, males and females were recorded 78 (56.52\%) and 60 (43.48\%) respectively which represent the total population sex ratio of 1:0.77 (Table 3). The percentages of males were comparatively higher in February (87.5\%) while the females were higher in July (62.5\%). The calculated value of chi-square $\left(x^{2}\right)$ was 9.54 which were significant at a $0.1 \%$ level of significance with $1^{0}$ of freedom. The calculated sex ratio in respect of season is represented in table 3 . There were no significant differences in sexes during the summer and rainy seasons. However, males were significantly $(p<0.05)$ dominated in winter (Table 4). The sex ratio of males and females (M: F) was recorded at 1:0.77 which differed from other studies where the overall sex ratio (M: F) was 1:1.08 (Hossain et al. 2013) and 1:1.11 (Mian et al. 2017). Although some finfish and prawn populations may show a strong bias in sex ratio 1:1 is not expected from most aquatic species (Hossain et al. 2012). However, in the case of season-wise distribution slightly disproportionate distribution was noticed in the sex ratio of $X$. cancila (Table 3 and 4). The chi-square test showed the monthly fluctuation of male and female distribution. Females were higher in number than the males in February, July, and August (Table 3). However, the lack of adequate information on the sex ratio of the species restrains the comparison with other studies.

Table 3. Sex ratio and chi-square $(X 2)$ value of $X$. cancila in different months collected from minor habitats in Jashore area, south-western Bangladesh

\begin{tabular}{lcccccccc}
\hline Months & Number $^{*}$ & Male & Female & \% Male & \%Female & M: F & $\chi^{2}$ & Remark \\
\hline April & 9 & 6 & 3 & 66.67 & 33.33 & $1: 0.50$ & 1.00 & Ns \\
May & 10 & 5 & 5 & 50 & 50 & $1: 1$ & 0.00 & Ns \\
June & 14 & 7 & 7 & 50 & 50 & $1: 1$ & 0.00 & Ns \\
July & 16 & 6 & 10 & 37.5 & 62.5 & $1: 0.75$ & 1.00 & Ns \\
August & 22 & 12 & 10 & 54.55 & 45.45 & $1: 0.83$ & 0.18 & Ns \\
September & 17 & 11 & 6 & 64.71 & 35.29 & $1: 0.55$ & 1.48 & Ns \\
October & 11 & 6 & 5 & 54.55 & 45.45 & $1: 0.50$ & 0.09 & Ns \\
November & 9 & 5 & 4 & 55.56 & 44.44 & $1: 0.80$ & 0.12 & Ns \\
December & 8 & 5 & 3 & 62.5 & 37.5 & $1: 0.60$ & 0.50 & Ns \\
January & 6 & 4 & 2 & 66.67 & 33.33 & $1: 0.50$ & 0.66 & Ns \\
February & 8 & 7 & 1 & 87.5 & 12.5 & $1: 0.14$ & 4.50 & S $^{*}$ \\
March & 8 & 4 & 4 & 50 & 50 & $1: 1$ & 0.00 & Ns \\
\hline
\end{tabular}

* $=$ Number of observations; Ns $=$ Non-significance, $\mathrm{S}=$ Significance. 
Table 4. Sex ratio and chi-square $(X 2)$ value of $X$. cancila in different seasons in different water habitats in Jashore area, south-western Bangladesh

\begin{tabular}{ccccccccc}
\hline Seasons & No. of obs* & Male & Female & \%Male & \%Female & M : F & $\chi^{2}$ & Remark \\
\hline Summer & 41 & 22 & 19 & 53.66 & 46.34 & $1: 0.86$ & 0.22 & Ns \\
Rainy & 66 & 35 & 31 & 53.03 & 46.97 & $1: 0.89$ & 0.24 & Ns \\
Winter & 31 & 21 & 10 & 67.74 & 32.26 & $1: 0.48$ & 3.90 & $S^{*}$ \\
\hline
\end{tabular}

*Obs = Observations; NS = Non-significance, $\mathrm{S}=$ Significance.

\section{Length-weight relationship}

The length-weight relationships of collected specimens were calculated in different aspects like different sexes, combined sex, and seasons. Values of constants "a" and "b" in the linear regression of various ways of calculation with respective of correlation " $r$ " value in $X$. cancila are given in Table 5. The $b$ values were 2.94 and 2.85 for male and female and 3.14, 3.05, and 2.39 in summer, rainy, and winter seasons respectively. The linear relationships were found in all the calculated aspects (Fig. 2 and 3). Highly significant linear length-weight relationships were found in respect of both sexes and different seasons. The exponent ' $b$ ' is the ratio of logarithmic growth rates for length and weight, the increment in log length for the same period (Le Cren 1951). The value of ' $b$ ' will be exactly 3 when the growth is isometric. The volume of similarity-shaped bodies of the same specific gravity varies directly as the cube of the corresponding dimension (cube law) (Allen 1938, Ricker 1963).

Growth is expected to be positive allometric when the weight of an organism increases more than length $(b>3)$. The parameter ' $b$ ' values vary between 2 and 4 ; however, values with a range from 2.5 to 3.5 are mostly found (Carlander 1969, Froese 2006). In the present study, the $b$ values were 2.94 and 2.85 for males and females of $X$. cancila (Table 5). The $b$ values were less than 3 in both sexes indicated the negative allometric growth pattern. Chandrika and Balasubramonian (1986) recorded the $b$ values as 2.90 and 2.83 which are closely related to the present study. However, the positive allometric growth pattern has been reported in X. cancila in the Ganges River, Northwestern Bangladesh (Hossain et al. 2013). They recorded b values 3.87 for males and 3.69 for females respectively. The differences in $b$ values can be attributed to several factors including habitat, area, seasonal effect, and differences in the observed length ranges of the specimen caught (Hossain 2010).

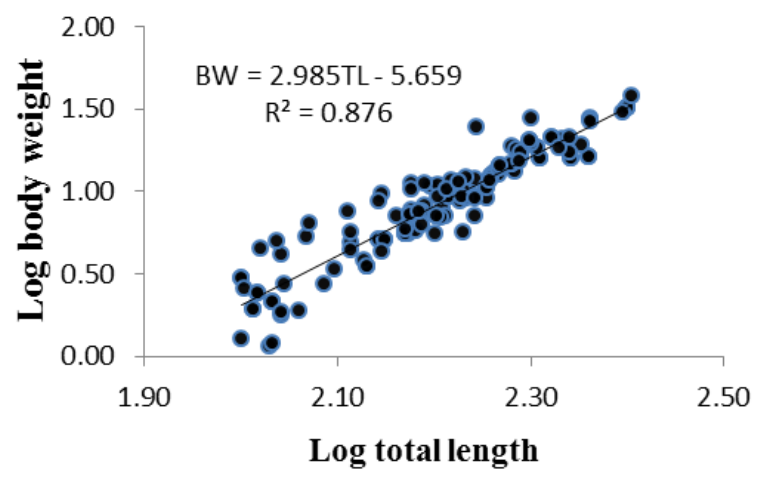

Fig. 2: Length-weight relationship of $X$. cancila $(n=138)$ in Jashore area, south-western Bangladesh (Size based). 

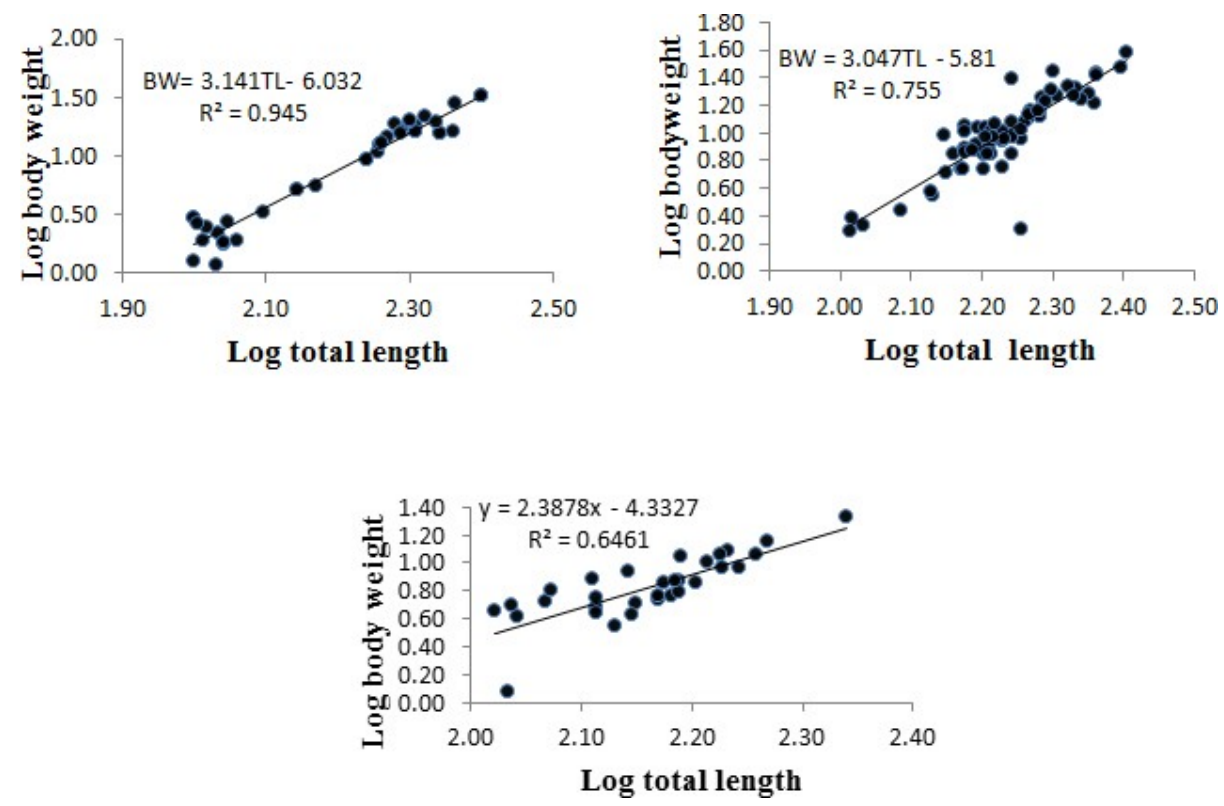

Fig. 3: Scatter diagram showing Length-weight relationship of $X$. cancila in different seasons (summer, rainy, and winter) in Jashore area.

Table 5. Values of constants "a" and " $b$ " in the linear regression of length-weight characteristics with though respective correlation " $r$ " value of $X$. cancila in different sexes and seasons

\begin{tabular}{ccccc}
\hline SI. No. & Characters & Intercept a & Regression $b$ & Correlation $r$ \\
\hline 1 & TL:BW (All) & -5.66 & 2.98 & 0.88 \\
2 & TL:BW (Male) & -5.57 & 2.94 & 0.77 \\
3 & TL:BW (Female) & -5.34 & 2.85 & 0.91 \\
4 & TL:BW (SS) & -6.03 & 3.14 & 0.94 \\
5 & TL:BW (RS) & -5.81 & 3.05 & 0.75 \\
6 & TL:BW (WS) & -4.33 & 2.39 & 0.65 \\
\hline
\end{tabular}

SS = Summer season; RS = Rainy season; WS = Winter season.

\section{Conclusion}

The basic information on morphometric characteristics, size-class distributions, length-weight relationships, and sex ratio of the present study would be useful to understand the population status of $X$. cancila in the different minor habitats of the fish in south-western Bangladesh and nearby such eco-system. It is also suggested to conduct details of the biological study of the fish from each different habitat in the region. 


\section{Acknowledgments}

The study was financially supported by the grant for advanced research in education (GARE), ministry of education, Peoples Republic of Bangladesh. We also thank the fishermen who cordially help us to take the samples around the year.

\section{References}

Alam M, Jahan S, Hussain M, De M, Goutham-Bharathi P, André M, Mazlan AG and Das S (2013). Length-length relationship, length-weight relationship and condition factor of freshwater fish species of Bangladesh. AACL Bioflux. 6: 498-509.

Allen KR (1938). Some observations on the biology of the trout (Salmo trutta) in Windermere. J. Anim. Ecol., 7: 333-349.

Al-Mamun A (2003). A Hand Guide for Identification of Inland Fishes of Bangladesh. World Fish Centre, Bangladesh. 2003.

Carlander KD (1969). Handbook of Freshwater Fishery Biology, Life History Data on Freshwater Fishes of the United States and Canada, Exclusive of the Perciformes. The lowa State University Press.

Chandrika B and Balasubramonian NK (1986). Length-weight relationship of Xenentodon cancila (Ham.) (Teleostei: Belonidae). Proceedings of Indian Academy of Science (Animal Science), 95(2): 187-190.

Froese R (2006). Cube law, condition factor and weight-length relationships: History, meta-analysis and recommendations. J. Appl. Ichthyol., 22: 241-253.

Froese R and Pauly D (2012). Fishbase World Wide Web electronic publication. Available at: http://www.fishbase.org.

Hasan MR, Hossain MY, Mawa Z, Tanjin S, Rahman MA, Sarkar UK and Ohtomi J (2021). Evaluating the size at sexual maturity for 20 fish species (Actinopterygii) in wetland (Gajner Beel) ecosystem, north-western Bangladesh through multi-model approach: A key for sound management. Acta Ichthyol. Piscat., 51(1): 29-36.

Hossain MA, Afsana K and Shah AKMA (1999). Nutrition value of some small indigenous fish species (SIS) of Bangladesh. Bangladesh J. Fish., 3(1): 77-85.

Hossain MY (2010). Length-weight, length-length relationships and condition factors of three schibid catfishes from the Padma River, Northwestern Bangladesh. Asian Fish. Sci., 23: 329-339.

Hossain MY, Jewel MAS, Rahman MM, Haque ABMM, Elbaghdady HAM and Ohitomi J (2013). Life history traits of the freshwater garfish Xenentodon cancila (Hamilton 1822) (Belonidae) in the Ganges River, Northwestern Bangladesh. Sains Malays., 42(9): 1207-1218.

Hossain MY, Sayed SRM, Rahman MM, Ali MM, Hossen MA, Elgorban AM, Ahmed ZF and Ohtomi J (2015). Lengthweight relationships of nine fish species from the Tetulia River, southern Bangladesh. J. Appl. Ichthyol., 31. 10.1111/jai.12823.

Hossain MY, Hossain MA, Pramanik MNU, Ahmed ZF, Hossain MA and Islam MM (2016). Length-weight and lengthlength relationships of three ambassid fishes from the Ganges River (NW Bangladesh). J. Appl. Ichthyol., 32: 12791281.

Hossain MY, Hossen MA, Ahmed ZF, Hossain MA, Pramanik MNU, Nawer F, Paul AK, Khatun D, Haque N and Islam MA (2017). Length-weight relationships of 12 indigenous fish species in the floodplain Gajner Beel (NW Bangladesh). J. Appl. Ichthyol., 33: 842-845.

Hussain MA, Khatun MA, Siddique MA, Flowra FA, Alam MM and Sultana S (2012). Morphometric characters of freshwater fish Xenentodon cancila collected from Rajshahi city, Bangladesh. J. Bio-Sci., 20: 171-177. 
Islam MR, Azom MG, Faridullah M and Mamun M (2017) Length-weight relationship and condition factor of 13 fish species collected from the Atrai and Brahmaputra rivers, Bangladesh. J. Biol. Environ.Sci., 10(3): 123-133.

Khatun D, Hossain MY, Nawer F, Mostafa AA and Al-Askar AA (2019). Reproduction of Eutropiichthys vacha (Schilbeidae) in the Ganges River (NW Bangladesh) with special reference to potential influence of climate variability. Environ. Sci. Pollut. Res., 26: 10800-10815.

Koutrakis ET, Kamidis NI and Leonardos ID (2004). Age, growth and mortality of a semi-isolated lagoon population of sand smelt, Atherina boyeri (Eisso, 1810) (Pisces: Atherinidae) in an estuarine system of Northern Greece. J. Appl. Ichthyol., 20: 382-388.

Le Cren ED (1951). The length-weight relationships and seasonal cycle in gonad weight and condition in the perch (Percafluviatilis). J. Anim. Ecol., 20: 201-219.

Mian S, Papree SD, Dey T, Hossain MA, Iqbal MM, Abol-Munafi AB and Islam MS (2017). Some reproductive aspects of freshwater garfish, Xenentodon cancila (Hamilton 1822) from North-East Bangladesh. J. Fish. Aquat. Sci., 12(2): 82-89.

Nahid MN, Latifa GA, Chakraborty SC, Farid FB and Begum M (2016). Biochemical and mineral composition and microbial quality of some selected freshwater small indigenous species (SIS) in Meghna River of Bangladesh. Int. J. Multidiscip. Res. Dev., 3(7): 352-357.

Nath P and Dey SC (1989). Fish and Fisheries of North East India. Arunachal Pradesh, 1: 1- 143.

Rahman AKA (1989). Freshwater Fishes of Bangladesh. Zoological Society of Bangladesh. Department of Zoology, University of Dhaka.

Rahman MA, Hasan MR, Hossain MY, Islam MA, Khatun D, Rahman O, Mawa Z, Islam MS, Chowdhury AA, Parvin MF and Khatun $\mathrm{H}$ (2019). Morphometric and meristic characteristics of the Asian stinging catfish Heteropneustes fossilis (Bloch 1794): A key for identification. Jordan J. Biol. Sci., 12: 467-470.

Ricker WE (1963). Hand book of computation for biological statistic of fish populations. Fisheries Research Board of Canada, 191(1): 82.

Sokal RR and Rohlf FJ (1987). Introduction to Biostatictics. $2^{\text {nd }}$ ed. New York: Freeman Publication.

Talwar PK and Jhingran AG (1991). Inland Fishes of India and Adjacent Countries. Oxford and LBH Publishing Co. Pvt. Ltd, New Delhi, Bombay and Calcutta, India, 12: 1063.

Tandon KK, Johal MS and Bala S (1993). Morphometry of Cirrhinus reba (Hamilton) from Kanjli wetland, Punjab, India. Res. Bull. Punjab. Univ. Sci., 43(1-4): 73-78.

Vazzoler AEAM (1996). Reproduction Biology of Teleostean Fishes: Theory and Practice. Maringá, EDUEM, Brazilian Society of Ichthyology.

Wu CC, Su WC and Kawasaki T (2001). Reproductive biology of the dolphin fish Corphaena hippurus on the east coast of Taiwan. Fish. Sci., 67: 784-793. 